\title{
PEMANFAATAN DAN KONSERVASI SUMBER AIR DALAM KEADAAN DARURAT
}

\author{
Seno Adi \\ Pusat Pengelolaan Sumberdaya Lahan, Wilayah dan Mitigasi Bencana Deputi TPSA, BPP Teknologi \\ JI. MH. Thamrin No. 8 Jakarta Pusat
}

\begin{abstract}
The need of clean water availability is the basic need of human being for living. In case of emergency, the clean water availability is still needed firstly. In this situation, we have to has a practical knowledge on water resource exploration as well as exploitation effectively and efficiently in such away the water utilization are sustainable. The water availability properties such as, quality, quantity, and site are related to the technology for water conservation and exploitation. Basically, the water availability in emergency could be developed based on the hydrological and hydro geological properties of the nearest location. In situ direct water utilization with bad water quality (in case of flooding) could be handled by using tools of water survival kit such as water bag, purification tablet or powder, and purification bottle. The water utilization in short term with limited scale (in case of refugees camp) could be developed by constructing shallow well (dig well or pumping well) if the shallow aquifer are available. The water utilization in medium term could be developed by constructing water conservation and exploitation system such as mini dam, infiltration galleries, spring water conservation, water seepage, and rain water harvesting.
\end{abstract}

Key words : sumber air, darurat, hidrologi, hidrogeologi, konservasi

\section{PENDAHULUAN}

\subsection{Latar Belakang}

Air merupakan sumberdaya alam yang jumlahnya tetap, namun tersebar secara tidak merata. Sudah disadari bahwa sumber air adalah sangat penting bagi kehidupan maupun untuk menunjang berbagai aktivitas pendukung kehidupan manusia. Pertambahan penduduk dan berkembangnya aktivitas manusia melalui industri telah mengakibatkan sumber-sumber air mengalami proses degradasi sumber daya air. Proses degradasi tersebut dapat dilihat dalam kehidupan sehari-hari yaitu dengan terjadinya kekeringan, kebanjiran, pencemaran sungai, sedimentasi.

Dengan semakin seringnya terjadi bencana, apalagi dalam skala luas dan masif, dimana pada umumnya akibat dari bencana tersebut, maka jumlah pengungsi akan juga cukup tinggi, sehingga diperlukan suatu sistem penyediaan air yang handal agar pengungsi dapat terhindar dari kekurangan pasokan sumber air bersih. Pengiriman sumber air dari luar lokasi pengungsian, apalagi diambil dari sumber yang jauh, selain akan merepotkan juga menjadi tidak ekonomis.

Permasalahan sumber air ini juga ternyata kait mengkait dengan ekosistem lainnya seperti kehutanan, pertanian, dan lahan basah. Saat ini sebagian besar penanganan masalah sumber air tersebut adalah baru terbatas pada aspek hidrologi saja, belum mencakup seluruh ekosistem lainnya. Padahal upaya pengelolaan sumber air dipengaruhi oleh seluruh dinamika ekosistem pembangunan. Secara umum peningkatan kegiatan pembangunan apapun dipastikan akan mendatangkan tuntutan makin tinggi terhadap sumber air.

$$
\text { Mengingat sangat pentingnya }
$$

ketersediaan air dalam kondisi darurat, maka diperlukan suatu pemanfaatan yang memungkinkan air dapat tersedia secara efisien, dengan kualitas yang memadai atau setara kualitas air bersih, dan dalam jumlah tertentu yang memadai, terutama pada saat seperti ini dimana justru ketersediaan air sangat minimal dan tidak memadai. Untuk mengatasi hal itu perlu dilakukan pendekatan survai lokasi secara sederhana maupun komprehensif (bila tersedia cukup waktu) sehingga dapat diidentifikasi berbagai cara pemanfaatan yang optimal.

\subsection{Tujuan}

Kegiatan ini bertujuan, antara lain :

- Mengetahui berbagai sumberdaya air setempat yang dapat digunakan secara cepat, tepat dan ekonomis dalam keadaan darurat berdasarkan karakteristik hidrologi dan hidrogeologi;

- Mengetahui berbagai alternatif teknologi pemanfaatan dan konservasi sumber air, terutama dalam jangka pendek dan menengah. Dalam jangka pendek adalah 
dalam rangka kondisi darurat menghadapi kekurangan ketersediaan air pada saat suatu kejadian bencana, terutama di tempat-tempat pengungsian korban bencana.

\subsection{Metodologi}

Metodologi kajian ini merupakan tinjauan pustaka dari berbagai sumber referensi terkait kondisi hidrologi, teknologi konservasi dan pemanfaatan sumber air, serta interpretasi dari beberapa peta tematik Atlas Regional Indonesia, khususnya untuk mengetahui potensi hidrologi dan hidrogeologi di Indonesia.

Pemanfaatan sumber air secara langsung berdasarkan pada ketersediaan teknologi untuk pengolahan air secara cepat dengan asumsi sumber air sudah ada, sedangkan pemanfaatan sumber air secara tidak langsung berdasarkan pada teknologi praktis konservasi sumber air, agar ketersediaannya berlanjut.

\section{TINJAUAN SUMBERDAYA AIR}

\subsection{Siklus Hidrologi}

Sebenarnya ketersediaan sumber air di alam jumlahnya relatif tetap yang menjad masalah adalah waktu ketersediaan yang berubah dan kualitasnya, karena air sebenarnya hanya mengalami proses perubahan bentuk dan perpindahan dari satu tempat ke tempat lain dimana proses tersebut dinamakan siklus hidrologi. Oleh karena itu dikenal adanya proses presipitasi (hujan), evaporasi (penguapan), transpirasi yang merupakan faktor utama terjadinya siklus hidrologi. Sumber panas dari matahari akan menjadikan air permukaan yang terutama berada di laut dan danau/waduk akan mengalami penguapan menjadi awan yang oleh angin awan tersebut akan terbawa ke daratan.

Pengumpulan awan-awan tersebut pada masanya akan mengalami kondensasi yang diakibatkan oleh proses fisika dan ketinggian sehingga akan berubah menjadi hujan. Selanjutnya hujan akan turun ke bumi yang mengisi sistem danau, sungai, air tanah, dan pada akhirnya akan kembali ke laut dan akan terjadi proses siklus lagi.

Dengan adanya siklus hidrologi, ketersediaan air di bumi tidak akan habis, hanya akan terjadi perpindahan air secara parsial yang diakibatkan oleh aktivitas manusia sebagai ketidak mampuan untuk tetap mempertahankan siklus tersebut ${ }^{(1)}$.Oleh karena itu persediaan air secara global tidak akan menjadi masalah, namun permasalahan akan muncul ketika manusia membuat suatu aktivitas seperti reklamasi rawa, penebangan hutan, yang dapat mengganggu proses siklus hidrologi tersebut.

\subsection{Kebutuhan Air}

Kebutuhan air pada setiap individu sebenarnya cukup bervariasi, akibat dari kebiasaan hidup dengan fasilitas yang ada, misalnya untuk yang hidup diperkotaan maka kebutuhan air akan lebih tinggi dari pada masyarakat yang hidup di pedesaan. Hal ini karena pada kehidupan kota biasanya ada tambahan penggunaan air untuk menyiram halaman, mencuci mobil, serta pamakaian air untuk toilet. Demikian juga musim akan sangat menentukan besarnya penggunaan air, pada musim kemarau akan lebih banyak pemakaian air dibanding musim hujan. Kebutuhan air minimal dapat dilihat pada Tabel 1.

Untuk kebutuhan air dalam keadaan minimal maka yang diperhitungkan terutama adalah untuk kebutuhan minum, toilet, dan kemudian mandi cuci. Pada Tabel 1 diketahui bahwa kebutuhan air minimal dalam keadaan minimal adalah kira-kira sebesar 40 liter/orang/hari. Kebutuhan akan bertambah apabila terdapat orang yang sakit dan harus dirawat.

Dalam menunjang kehidupan manusia dewasa kira-kira diperlukan 2 liter air untuk proses metabolisme tubuh manusia. Peranan air dalam tubuh manusia dapat diketahui sebagai berikut(2) : sebagai pelarut dan alat pengangkut, fasilitator pertumbuhan, alat pelicin, katalisator, pengatur suhu tubuh, dan sumber mineral.

Tabel 1. Kebutuhan air minimal(3)

\begin{tabular}{|c|l|c|}
\hline No & \multicolumn{1}{|c|}{ Aktivitas } & $\begin{array}{l}\text { Kebutuhan air } \\
\text { (liter/org/hari) }\end{array}$ \\
\hline 1 & $\begin{array}{l}\text { Minimum hidup } \\
\text { (minum) }\end{array}$ & $3-5$ \\
3 & $\begin{array}{l}\text { Kebutuhan dasar } \\
\text { (mandi, cuci) }\end{array}$ & $15-20$ \\
4 & $\begin{array}{l}\text { Pusat Kesehatan } \\
\text {-Pasien rawat jalan }\end{array}$ & 5 \\
5 & $\begin{array}{l}\text {-Pasien rawat inap } \\
\text { Toilet }\end{array}$ & $40-60$ \\
& $\begin{array}{l}\text {-Kloset jongkok } \\
\text {-Closet monoblok }\end{array}$ & $2-8$ \\
$20-50$ \\
\hline
\end{tabular}

\subsection{Ketersediaan Sumberdaya Air}

Secara keseluruhan ketersediaan air dibumi dapat dikelompokkan dalam 7 tempat sumber air. Diketahui bahwa persentase keberadaannya dengan volume terbesar berada dilaut dan selanjutnya airtanah dan air permukaan seperti pada Tabel 2 sebagai berikut. 
Tabel 2 Perkiraan jumlah air di dunia(4)

\begin{tabular}{|c|l|c|c|}
\hline No & $\begin{array}{c}\text { Lokasi } \\
\text { Sumber air }\end{array}$ & $\begin{array}{c}\text { Volume } \\
\left(\mathbf{1 0}^{6} \mathbf{K m}^{\mathbf{3}}\right)\end{array}$ & $\%$ \\
\hline \hline 1 & Lautan & 1.370 & 94,2 \\
\hline 2 & Air tanah & 60 & 4,13 \\
\hline 4 & Air permukaan & 0,28 & 0,019 \\
\hline 5 & Tanah & 0,08 & 0,0055 \\
\hline 6 & Sungai & 0,0012 & 0,00008 \\
\hline 7 & Atmosfir & 0,014 & 0,00096 \\
\hline
\end{tabular}

Air laut merupakan sumber air terbesar di muka bumi, diperkirakan terdapat $94,2 \%$ sumber air berada di laut, sebagai mana diketahui adalah bahwa wilayah Indonesia $70 \%$ terdiri dari lautan sehingga dibayangkan kekayaan sumber air kita di laut. Namun demikian kualitas air laut tidak dapat digunakan untuk air rumah tangga (minum, mandi dan cuci), sehingga pemanfaatannya saat ini lebih tepat adalah untuk produksi perikanan maupun wisata dan transportasi. Sampai saat ini pengubahan air laut menjadi air untuk rumah tangga masih memerlukan biaya tinggi yaitu melalui proses desalinasi. Untuk negara-negara tertentu yang sulit air seperti di Saudi Arab melakukan desalinasi atau penyulingan air laut menjadi air tawar karena sangat terbatasnya air tawar.

Air laut ini juga menjadi masalah pada saat terjadi instrusi air laut ke arah daratan sebagai akibat terjadinya perubahan debit aliran sungai terutama pada saat musim kemarau sehingga menjadi perubahan keseimbangan tekanan aliran yang mengakibatkan air laut mendesak ke arah daratan melalui sungai. Hal ini menyebabkan permasalahan terhadap pertanian pasang surut dan intake (tempat pengambilan air minum PAM). Kejadian seperti ini banyak terjadi di Kalimantan dan Sumatra dimana terdapat dataran rendah luas yang dipengaruhi pasang surut.

\subsubsection{Air Permukaan}

\subsubsection{Air Sungai}

Pada dasarnya air sungai berasal dari sumber-sumber mata air yang bergabung dan aliran dasar air tanah, maupun yang langsung dari air hujan berupa limpasan air yang tidak meresap ke dalam sistem air tanah. Kontak langsung air sungai ini dengan permukaan tanah menyebabkan sungai-sungai menjadi sangat rawan terhadap pencemaran, terutama pada daerah yang sudah terbangun seperti kota atau kawasan berpenduduk padat, bahkan pada daerah pertanian yang intensif. Pada umumnya air sungai ini digunakan untuk keperluan irigasi pertanian dan proses industri maupun untuk keperluan rumah tangga. Terdapat sungai bawah tanah yang pada umumnya terdapat pada daerah berkapur (karst) seperti yang terjadi di Gunung Kidul.

\subsubsection{Mata Air}

Mata air merupakan sumber air yang muncul dengan sendirinya ke permukaan tanah. Sumber air ini pada umumnya kualitasnya sangat baik sebagai sumber air minum karena telah mengalami purifikasi secara alami (self purification) melalui lapisan-lapisan pasir yang juga merupakan lapisan pembawa air (aquifer) ${ }^{(5)}$. Sumber mata air ini juga terdapat di dalam laut misalnya yang terjadi di daerah Tuban, Jawa Timur atau di Bardu, Yogyakarta. Pada umumnya sumber mata air ini terdapat di sekitar kaki pegunungan yang biasanya masih merupakan kawasan hutan yang berfungsi sebagai penahan air pada saat musim hujan dan mengeluarkan melalui sistem mata air. Dengan demikian berkurangnya kawasan hutan yang terjadi saat ini maka debit mata air akan berkurang seperti yang terjadi di Jawa.

\subsubsection{Air Tanah}

\subsubsection{Air Tanah Dangkal}

Air tanah dangkal pada umumnya berada pada kedalaman $0-40 \mathrm{~m}$. Karena letak lapisan air tanah ini langsung berhubungan dengan permukaan tanah, maka kualitas air tanah sangat tergantung dari aktivitas penggunaan tanah diatasnya, dan ketersediaannya sangat terpengaruh oleh musim. Pada daerah perkotaan kualitas air tanah biasanya mudah tercemar oleh limbah domestik, terutama yang berasal dari septic tank. Keadaan ini meyebabkan kualitas air tanah yang pada umumnya sebagai sumber utama air minum di pedesaan atau di kawasan kota yang belum terjangkau air PAM menjadi sangat rawan terhadap penularan penyakit perut seperti diare, kolera, tipus.

\subsubsection{Air Tanah Dalam}

Sesuai namanya, maka air tanah dalam pada umumnya terdapat pada kedalaman di atas $40 \mathrm{~m}$. Karena letaknya yang sangat dalam maka pada umumnya kualitas lebih baik dari pada air tanah dangkal karena sumber airnya berasal jauh dari dimana diketemukan yaitu dari resapan dibagian hulu. Namun demikian kualitas air tersebut terkadang tidak baik karena pengaruh lingkungan pengendapan geologi(5) .

Pemanfaatan air tanah dalam ini biasanya untuk keperluan industri karena proses mendapatkannya yang relatif mahal untuk keperluan rumah tangga yaitu harus mengebor 
sampai kedalaman 100-200m untuk memperoleh lapisan air yang potensial. Saat ini air dalam kemasan yang banyak dijual pada umumnya berasal dari sumber air tanah dalam dan biasanya hanya dilakukan proses suci hama (disinfectant) dan langsung dikemas, sehingga tidak perlu dilakukan proses pengolahan air seperti halnya yang berasal dari air sungai.

\subsubsection{Air di Atmosfir}

Seperti dijelaskan dalam siklus hidrologi yaitu terjadi proses penguapan dari air permukaan ke udara, maka diatmosfir sebenarnya mengandung sumber air berupa uap air yang siap menjadi air hujan setelah mengalami kondensi. Jumlah hujan di indonesia berkisar antara $1500 \mathrm{~mm} /$ pertahun didaerah pantai hingga mencapai $3000 \mathrm{~mm} /$ tahun didaerah pegunungan merupakan jumlah yang cukup tinggi.

Pada beberapa daerah pegunungan bahkan dapat mencapai $4000 \mathrm{~mm} /$ tahun seperti yang terjadi disekitar Bogor(6). Hanya sayangnya distribusi curah hujan tersebut tidak merata sepanjang tahun, sebagian besar $(80 \%)$ terjadi dimusim hujan sehingga pada musim kemarau kita akan mengalami kekurangan air.

Teknologi saat ini mampu membuat proses kondensi dilakukan adalah melalui teknologi modifikasi cuaca atau yang lebih dikenal dengan sebutan hujan buatan. Namun demikian hujan buatan ini juga memerlukan persyaratan-persyaratan alam seperti adanya potensi awan, kelembaban minimal, dan kecepatan angin maksimal(7). Pemanfaatan teknologi ini juga pada intinya adalah untuk memperpanjang atau membuat lebih awal masa jatuhnya musim hujan.

Sejauh ini teknologi hujan buatan masih efektif bila dilakukan pada suatu Daerah Aliran Sungai (DAS) yang memiliki waduk untuk keperluan energi (PLTA), sehingga jumlah air yang berhasil diturunkan dapat dikonversi dalam bentuk nilai ekonomis sebagai sumber energi dan produk sampingnya adalah untuk pengairan irigasi.

Teknologi pemanenan hujan (rainwater harvesting) juga merupakan alternatif penyediaan air pada daerah yang memiliki kualitas air permukaan buruk atau kesulitan sumber air, atau pada daerah daerah kering, seperti di Indonesia bagian timur, yang dikenal dengan nama embung

\section{HASIL DAN PEMBAHASAN \\ 3.1. Pemanfaatan Sumber Air Secara Langsung}

Pada pemanfaatan sumber air secara langsung adalah dimana sumber air sudah tersedia, meskipun dalam kondisi tidak memadai, khususnya dari segi kualitas, (misalnya dalam kejadian bencana banjir, sehingga sumber air dapat dapat langsung digunakan sebagai air bersih ataupun air minum, dimana untuk menjadikan sumber air yang sudah tersedia tersebut menjadi layak pakai secara cepat, maka dapat digunakan berbagai alternatif dengan menggunakan suatu peralatan dalam sekala personal secara efektif (survival kit) ${ }^{(8)}$.

> Tas penyimpan air (water storage bag); merupakan tempat penyimpanan air jinjing dari bahan PVC yang fleksibel, dengan kapasitas sekitar 10 liter, sehingga mudah dibawa. Sedangkan pada saat kosong dapat dilipat atau dikempeskan.
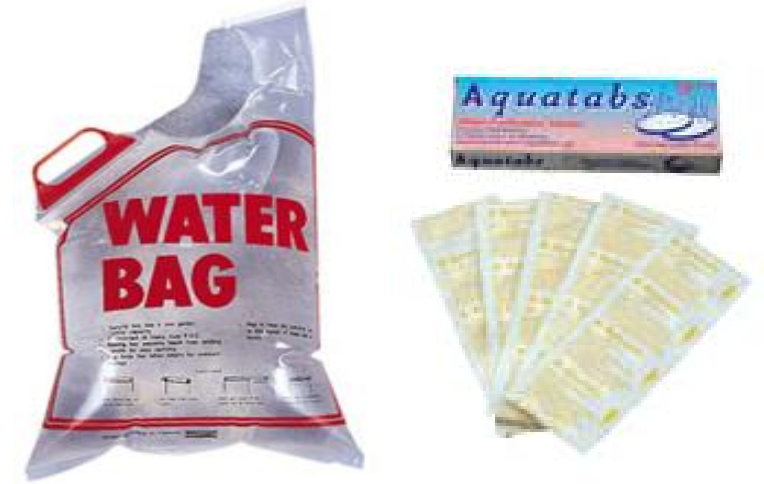

Tas air

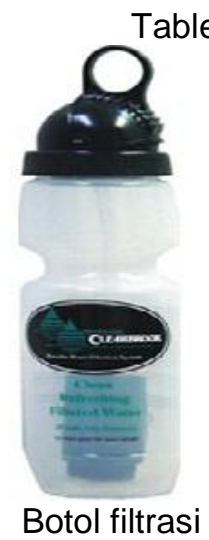

Gambar 1. Bebagai peralatan untuk pemanfaatan sumber air secara langsung(8)

Tablet atau bubuk purifikasi air (water purification tablet): adalah suatu bahan kimia yang dapat digunakan untuk menjadikan suatu sumber air menjadi air layak minum, yang pada umumnya dilakukan dengan proses koagulasi dan disinfektasi.

Botol filtrasi air (water filtration bottle): yaitu alat untuk menyaring air agar dapat digunakan untuk keperluan tertentu, misal mandi dan cuci. Alat ini mampu 
menghilangkan $99 \%$ beberapa parameter sebagai berikut:

- Estetika : bau, lumpur, pasir, sedimen;

- Mikroba : bakteri patogen :

- Kimia: POC, PCB, pestisida, detergen

- Padatan terlarut: berbagai logam berat

\subsection{Pemanfaatan Sumber Air Secara Tidak Langsung}

Pendekatan pemanfaatan secara tidak langsung adalah dimana sumber air harus dibuat suatu perlakuan tertentu dengan cara praktis dan relatif murah, sehingga dapat dimanfaatkan secara ekonomis. Beberapa contoh gambar berikut ini bersumber dari Davis dan Lambert, $1997^{(3)}$

\subsubsection{Air Permukaan}

\section{a. Pengalihan Aliran}

Merupakan suatu upaya memanfaatkan aliran sungai atau memompa kesisi badan sungai, dan kemudian dilakukan proses penyaringan. Pada keadaan darurat maka sebisa mungkin memanfaatkan bahan alam seperti batu, karung pasir (sandbag), sehingga struktur bangunan tidak permanen. Sistem ini terdiri dari bangunan untuk air masuk (inlet) yang ujungnya ditempatkan saringan kerikil kasar, kemudian masuk ke bak pengendapan dan penyaringan. Dari bak tersebut maka dibagian bawah dibuat saluran buangan kembali ke sungai dan saluran pendistribusian air yang sudah relatif bersih (Gambar 2)

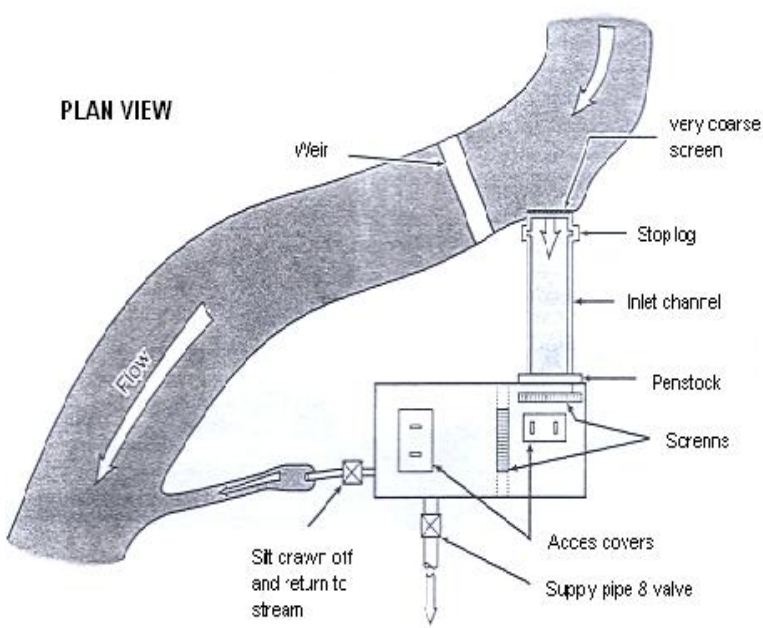

Gambar 2. Pengalihan sungai

b. Infiltrasi Galeri

Cara ini dapat dilakukan di bantaran sungai maupun di badan sungai (Gambar 3 ).
Pada prinsipnya cara ini terdiri dari saluran pipa yang dibenamkan kedalam dasar sungai yang sebelumnya dibuat lapisan krikil yang akan menyelimuti pipa tersebut. Saluran pipa yang dilengkapi dengan saringan, atau lubang-lubang kecil pada pipa dapat langsung dipompa keatas atau secara tidak langsung yaitu ditampung dulu pada suatu bangunan bak air secara hidraulika akan mengisi bak tersebut sama tinggi dengan muka air sungai, dan dari bak tersebut selanjutnya dipompa keatas.
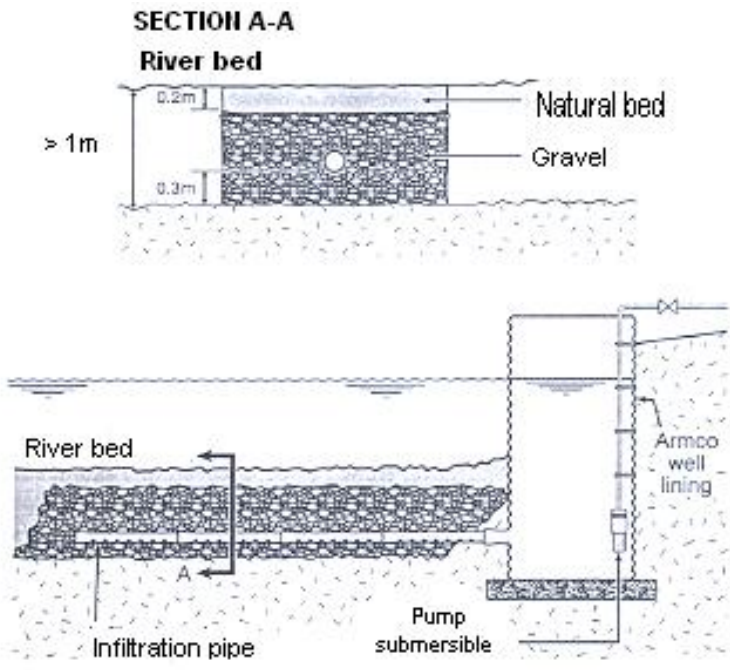

Gambar 3. Infiltrasi galeri

\section{c. Dam Mini}

Pembuatan dam kecil tersebut pada umumnya ditujukan adalah sebagai penambah simpanan air hujan berupa waduk kecil sehingga tidak langsung menjadi limpasan air, terutama pada saat musim kemarau. Selain itu juga untuk meresapkan air ke dalam sistem air tanah. Karena sebenarnya pembuatan dam tersebut memerlukan keahlian dan pengetahuan yang memadai, serta adanya konsekuensi perijinan dan dampak sosial ekonomi, terutama dibagain hilirnya, oleh karenanya pembuatan dam kecil tersebut sebaiknya hanya untuk kedalaman air 2 $\mathrm{m}$ yang terdiri dari $3 \mathrm{~m}$ tinggi bendung dgn $1 \mathrm{~m}$ tinggi air bebas. Bagian hulu dari lokasi bendung ini harus dipastikan memiliki tingkat erosi yang rendah, untuk menghindari sedimentasi dan pendangkalan. Bahan pembuatan dam tersebut secara mudah adalah dengan menggunakan material $20-30 \%$ lempung yang dicampur dengan pasir dan kerikil, serta sedikit lanau (earth dam).

Dam mini darurat dengan ketinggian $1 \mathrm{~m}$ dapat segera dibuat dengan cepat dengan bahan karung bekas terigu yang diisi lempung dan ditempatkan pada dasar sungai berbatu. Selain itu juga bendung sederhana dapat dibuat dengan batang kayu, dan timbunan tanah (Gambar 4) 


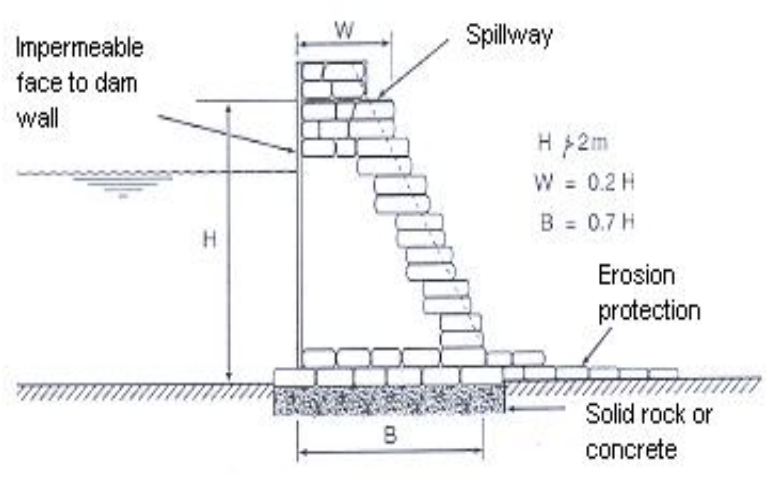

Gambar 4. Konstruksi dam mini

\subsubsection{Air Tanah}

\section{a. Dam Bawah Permukaan Tanah}

Suatu upaya menangkap air tanah dengan membuat konstruksi dam dibawah permukaan tanah sehingga mampu menahan aliran airtanah disuatu tempat (Gambar 5). Kondisi hidrogeologi lokal akan sangat mempengaruhi keberhasilan dam tersebut. Lokasi dam ini pada umumnya pada posisi adanya parit (trench), lembah atau sungai dengan lapisan pasir dan lapisan bawahnya adalah bersifat kedap air. Keuntungan dari dari dam tersebut adalah sebagai berikut:

- evaporasi sangat rendah karena sumber air dibawah tanah;

- tidak terpengaruh proses siltasi sehingga daya tampung air tetap;

- pencemaran rendah karena bukan merupakan perairan terbuka dan terjadi purifikasi secara alami;

- tidak menjadi tempat bersarangnya berbagai sumber penyakit.

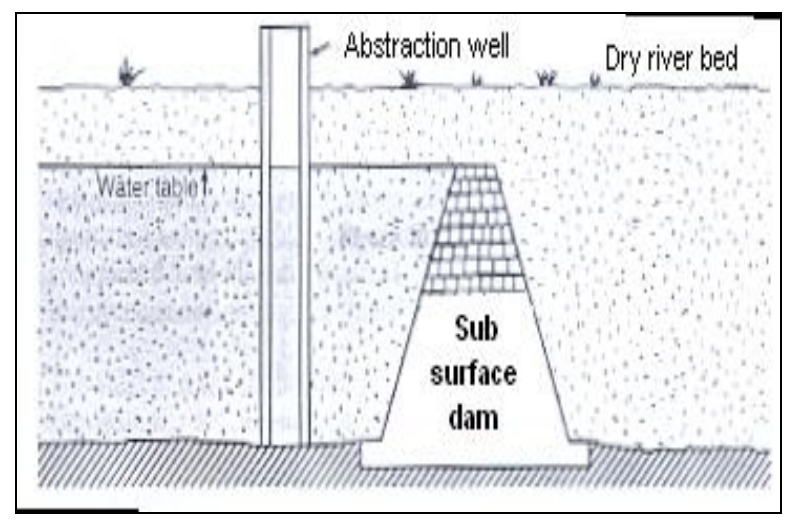

Gambar 5. Konstruksi dam bawah permukaan

Pembangunan dam ini pada umumnya hanya efektif dilakukan pada saat musim kemarau, sehingga tidak diperlukan proses pengeringan (dewatering). Berbagai bahan yang dapat digunakan untuk dam ini adalah : lempung, batu, tembok bata, beton, ferosemen, lembaran baja, lembaran plastik. Untuk keperluan darurat bangunan konstruksi dengan sistem injeksi (geotextile, semen, bentonit) dan penancapan lembaran baja (sheet piling) tampaknya paling cepat dapat dilakukan karena tidak diperlukan penggalian maupun pengeringan air (dewatering) sehingga dapat dikerjakan pada musim hujan sekalipun. Dengan sistem injeksi tersebut untuk kedalaman dam sampai dengan $10 \mathrm{~m}$, tembok bata dan beton $6 \mathrm{~m}$, ferosemen $4 \mathrm{~m}$, lempung 3 $\mathrm{m}$, dan plastik $2 \mathrm{~m}$.

\section{b. Mata Air}

Adanya sumber mata air ini harus dilakukan sistem perlindungan untuk melindungi dari kontaminasi dan menjaga kelestariannya. Terdapat dua cara untuk sistem perlindungan sumber mata air yaitu dengan bangunan konstruksi beton dan bukan beton sebagai berikut:

- Bangunan pelindung konstruksi beton berbentuk persegi atau bulat dengan bagian atas tertutup namun dapat dibuka untuk fungsi kontrol dan perawatan (Gambar 6). Dari bangunan tertutup tersebut dihubungkan dengan pipa kesuatu tempat secara gravitasi sehingga dapat manfaatkan airnya.

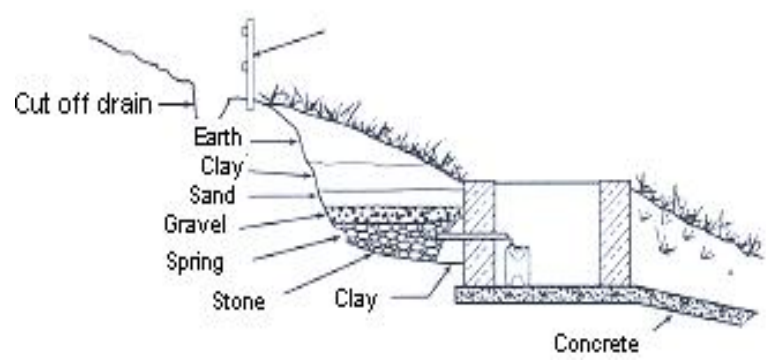

Gambar 6. Sistem pelindung mata air dari beton

- Bangunan pelindung bukan beton juga dapat dilakukan yaitu dengan melakukan penggalian dan melapisnya dengan lapisan kerikil pada bagian dasar dimana terdapat mata air, dan dibagian atasnya dengan lapisan pasir, selanjutnya pada permukaan dengan lapisan lempung yang ditamani rumput (Gambar 7). Dari lapisan kerikil dihubungkan dengan pipa secara gravitasi sedangkan pada ujung pipa yang berada pada lapisan kerikil dilengkapi saringan agar lapisan kerikil tidak masuk kedalam pipa air. Dengan sistem perlindungan tersebut maka sumber mata air dapat dimanfaatkan tanpa menganggu sumbernya yang memiliki resiko kerusakan atau terkontaminasinya sumber mata air. 


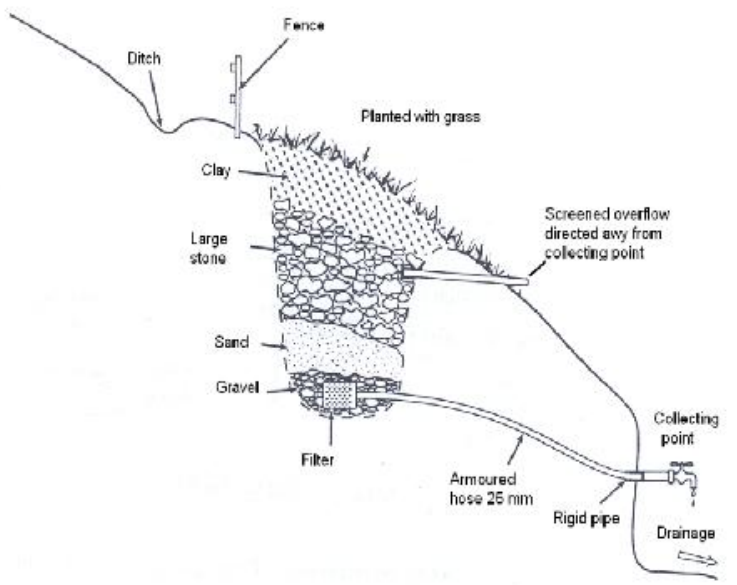

Gambar 7. Sistem pelindung mata air secara alami dengan filter mini

\section{c. Rembesan}

Pada prinsipnya pada lapisan bawah tanah akan terdapat lapisan pembawa air (aquifer) yang besar aliran dan kedalaman dari permukaan tanah sangat tergantung dari lokal hidrogeologinya. Apabila diketahui bahwa terdapat lapisan airtanah yang relatif dangal maka rembesan airtanah tersebut dapat dimanfaatkan sebagai sumber air bersih dengan sistem koleksi rembesan. Upaya tersebut dapat dilakukan dengan membuat galian parit (sampai mencapai lapisan kedap air) yang memotong lereng menuju kesuatu tempat sedemikian rupa sehingga fungsi gravitasi aliran air terkumpul pada suatu titik pengumpul. Pada galian parit tersebut dibagian bawah diisi dengan lapisan kerikil, pasir dan tutupan tanah dibagian atas (Gambar 8). Selanjutnya pada titik pengumpul dibuat bak penampung air. Dengan cara ini maka air rembesan tanah dapat dimanfaatkan sebagai air bersih.

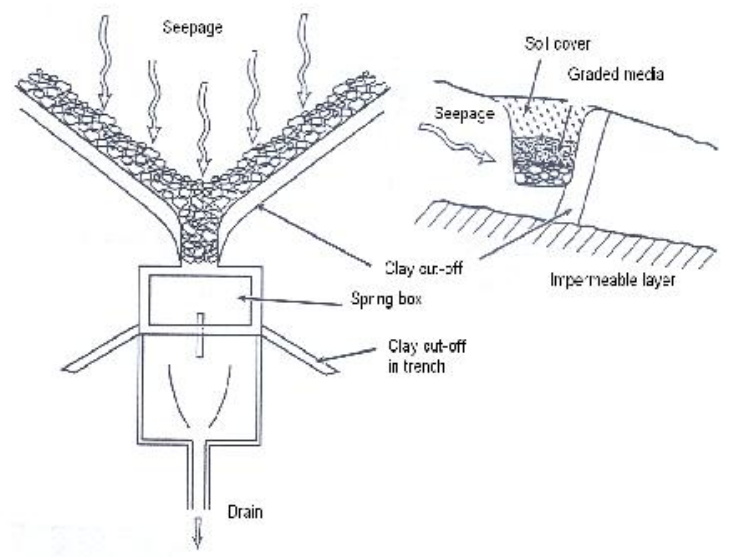

Gambar 8. Sistem kolektor rembesan air
Pada dasarnya pemanfaatan air tanah melalui sumur ini dapat dibagi menjadi sumur dangkal (<40 m) dan sumur dalam (> $40 \mathrm{~m}$ ). Kondisi hidrogeologi dan besarnya kebutuhan air akan dapat menentukan apakah lebih efisien dengan memanfaatkan sumur dalam atau sumur dangkal. Namun sudah pasti bahwa pembuatan sumur dalam memerlukan biaya yang sangat mahal, terutama untuk biaya pemboran dan survey hidrogeologinya untuk menentukan titik pemboran yang paling efisien.

Dalam keadaan darurat maka pembuatan sumur dangkal merupakan suatu alternatif yang paling murah. Sumur dangkal dapat berupa sumur gali, atau sumur pantek yang dilengkapi dengan pompa tangan atau pompa listrik. Dengan sumur gali dalam keadaan baik pada umumnya dapat memasok air untuk kebutuhan s/d 300 orang per hari(5) .

\subsubsection{Air Hujan}

Pemanfaataan air hujan sebagai sumber air biasanya dilakukan melalui atap rumah atau atap tenda dapat dilakukan dengan memanfaatan talang air yang terbuat dari berbagai bahan (seperti bambu, PVC, seng) mengalirkannya kebawah dan menampungnya pada drum, bak air atau tangki air. Tangki air penyimpan air hujan ini dapat diletakkan ditempat terbuka atau dipendam didalam tanah. Keuntungan dipendam didalam tanah adalah bahwa tangki tersebut tidak memerlukan ruang dipermukaan tanah, dan terlindung, namun kekurangannya adalah sulit dalam hal perawatannya.

Upaya seperti ini diberbagai tempat di Indonesia sudah banyak dilakukan karena untuk keperluan sehari-hari mengalami kesulitan air bersih. Terutama pada kawasan dengan keterbatasan sumber air bersih seperti di daerah lahan gambut upaya pemanfaatan air hujan dipandang lebih ekonomis, khususnya untuk kebutuhan minum dan masak, sedangkan untuk kebutuhan mandi dan cuci masih menggunakan sumber air sungai atau air tanah yang kualitasnya kurang baik seperti yang terjadi di kawasan gambut di Kabupaten Siak (9).

\section{KESIMPULAN}

Pada setiap kejadian bencana, khususnya bencana dalam sekala luas, selalu akan menimbulkan adanya pengungsi karena rusaknya tempat tinggal dan sarana penunjang hidup yang terkena bencana. Oleh karena itu diperlukan suatu tempat pengungsian dari korban bencana tersebut dengan sarana pendukung

d. Sumur 
yang memadai, dimana sarana utama yang harus ada dengan cepat adalah ketersediaan air. Air merupakan kebutuhan utama untuk dapat menunjang berbagai aktivitas manusia, oleh karena itu maka tuntutan ketersediaan air tetap harus dipenuhi paling tidak dalam batas kebutuhan dasar. Penyediaan air dapat dengan memanfaatkan berbagai sumber air yang ada yaitu air permukaan, air tanah, dan air hujan. Untuk itu diperlukan pengetahuan yang memadai mengenai kondisi hidrologi dan hidrogeologi setempat sehingga dapat dilakukan upaya penyediaan air secara darurat yang paling tepat dan efisien.

Air tanah pada umumnya memiliki kualitas yang baik, dibandingkan dengan air permukaan, sehingga relatif tidak memerlukan proses pengolahan sebagai sumber air bersih. Secara alami lapisan tanah telah menyaring air permukaan menjadi air tanah, dan sumber air terlindung dari berbagai zat pencemar yang sering terjadi pada air permukaan.

Oleh karena itu, dari berbagai teknologi penyediaan air secara darurat yang tersedia, apabila diketahui karakteristik hidrogeologinya secara sepintas, maka pembuatan sumur gali atau sumur pompa dangkal merupakan suatu alternatif yang paling efisien karena relatif dapat dilakukan dengan mudah, tanpa pengolahan air, dan tanpa pemeliharaan. Namun demikian ketersediaan air dari sumber ini, khususnya air tanah dangkal sangat terbatas dan dipengaruhi musim, sedangkan pemanfaatan sumber air tanah dalam (confined aquifer) memerlukan penyelidikan hidrogeologi yang cukup detil lebih dahulu

Pemanfaatan air secara langsung dalam keadaan darurat dapat dilakukan dengan perlengkapan survival kit berupa tempat air yang dapat dikempeskan atau galon air, tablet atau bubuk purifikasi, dan botol filtrasi. Hal ini dapat dilakukan bila sumber air sudah tersedia namun dalam keadaan tidak layak digunakan sebagai air bersih atau air minum.

Sementara itu untuk ketersediaan air secara darurat dalam jangka yang lebih lama lagi adalah dengan penyelidikan karakteristik hidrologi dan hidrogeologi setempat secara lebih detil, sehingga dapat dibuat sistem penyediaan air dalam jumlah yang lebih besar dengan mempertimbangkan keberlanjutan pasokan serta kemudahan operasional dan pemeliharaannya.

\section{DAFTAR PUSTAKA}

1. Smith, D.I., dan Stopp, P., 2004, The river Basin, An Introduction to Study of Hydrology, Cambridge University Press, London, New York, Melbourne, Sydney.
2. Sitepoe, M, 2003, Air untuk Kehidupan, Pencemaran Air dan Usaha Pencegahannya, Gramedia, Jakarta.

3. Davis, J. dan Lambert, R., 1997, Engineering in Emergencies, A Practical Guide for Relief Workers, Intermediate Technology Publication Ltd., London, UK

4. Shaw, E, 2004, Hydrology in Practice, Van Nostrand Reinhold (Internatioanl) Co. Ltd, London, UK.

5. Bouwer, H., 2001, Groundwater Hydrology, McGraw-Hill Series in Water Resources and Environmental Engineering, Kogakusha, Ltd, Tokyo.

6. Sandy. I Made, 1995, Atlas Republik Indonesia, Jurusan Geografi, FMIPA Universitas Indonesia, Depok.

7. Tempo Interaktif, 2003, Hujan Buatan di Jawa Barat dan Jawa Tengah mulai 1 Oktober 2003. Tempo Interaktif 24 September 2003.

8. www.quakekare.com/emergency-supplieskits/

9. Adi,S., 2008, Analisis Ketersediaan Air Domestik dalam Menunjang Pengembangan Wilayah, Jurnal Alami, Volume 13, No. 1, 2008, Jakarta 


\section{DATA PENULIS}

Seno Adi, Lahir di Malang, 8 September 1956, lulus Sarjana S1 Geografi, Universitas Indonesia tahun 1983, lulus Sarjana S2 Hidrologi, University of Mancester, Inggris, tahun 1991. Telah mengikuti berbagai pelatihan dibidang Sistem Informasi Geografi, Biogeokimia Lingkungan, Analisa Dampak Lingkungan, Air dan Karbon. Sejak tahun 1983 sampai sekarang bekerja di BPPT, saat ini sebagai peneliti Madya di Pusat Teknologi Lahan, Wilayah, dan Mitigasi Bencana.

\section{Abstract}

Kebutuhan akan ketersediaan air bersih merupakan kebutuhan dasar yang harus dipenuhi untuk menunjang kehidupan manusia. Demikian pula dalam keadaan darurat dan mendesak, diperlukan suatu pengetahuan untuk memanfaatkan sumber air setempat secara efektif dan efisien, sehingga pemanfaatannya dapat terus berlanjut. Lokasi ketersediaan sumber air baku sangat menentukan teknologi konservasi dan pemanfaatannya. Demikian juga jumlah, mutu, waktu dan ruang sangat menentukan metode konservasi dan pemanfaatannya. Pada dasarnya pemanfaatan sumber air secara darurat dapat dilakukan berdasarkan ketersediaan sumber air terdekat dengan memahami kondisi hidrologi dan hidrogeologi setempat, sehingga dapat dipilih suatu sistem pemanfaatan yang tepat. Pemanfaatan sumber air secara in situ pada lokasi pengungsian untuk sekala terbatas adalah melalui pemanfaatan sumur air tanah dangkal apabila terdapat lapisan airtanah yang memadai. Sedangkan pemanfaatan secara langsung, apabila sumber air sudah tersedia namun dalam kualitas yang tidak layak (misalnya pada bencana banjir), maka dapat dilakukan dengan peralatan survival kit seperti tas air fleksibel, tablet atau bubuk purifikasi, dan botol purifikasi.

Kata kunci: sumber air, darurat, hidrologi, hidrogeologi, konservasi

\section{Abstract}

The need of clean water availability is the basic need of human being for living. In case of emergency, the clean water availability is still needed firstly. In this situation, we have to has a practical knowledge on water resource exploration as well as exploitation effectively and efficiently in such away the water utilization are sustainable. The water availability properties such as, quality, quantity, and site are related to the technology for water conservation and exploitation. Basically, the water availability in emergency could be developed based on the hydrological and hydrogeological properties of the nearest location. In situ direct water utilization with bad water quality (in case of flooding) could be handled by using tools of water survival kit such as water bag, purification tablet or powder, and purification bottle. The water utilization in short term with limited scale (in case of refugees camp) could be developed by constructing shallow well (dig well or pumping well) if the shallow aquifer are available. The water utilization in medium term could be developed by constructing water conservation and exploitation system such as mini dam, infiltration galleries, spring water conservation, water seepage, and rain water harvesting.

Key words: water resources, emergency, hydrology, hydrogeology, conservation, utilization 